\title{
PHARMACOLOGIC HIBERNATION IN LUNG SURGERY FOR THE TUBERCULOUS PATIENT
}

\section{J. P DeChêNe, M D*}

THE FORMER haZARDOus operations in the open thorax, that frequently resulted in cardio-respiratory collapse, with resultung ciculatory or respiratory hypoxaemia, have been rendered relatively safe procedures, through endotracheal anaesthesia with controlled respuration including positive inspiratory and negative expiratory phases. Despite these recent advances in the field of anaesthesia, operational mortality is still hampering chest surgery. The causes are usually sudden depletion in blood volume through haemorrhage, disturbances of the gas-exchange mechanısm, which cannot be safely avorded despite good and prompt aspuration and even the use of special endobronchial anaesthesia with Carlens Tube. Hypoxaemia is also brought on by excessive reduction of the respiratory reserves. The final result of circulatory or respiratory hypoxia is cerebral coma and complete collapse of circulatory regulation Although unconsciousness and collapse are sometimes reversible, an unfortunate end cannot always be avorded. Especially is this true because patients in need of chest surgery are, on account of their disease, poor anaesthetic risks, and in some cases, where the disease is extensive, or some other organic or psychological factor is present, very poor risks

Recognizing the importance of an optimal oxygen supply for the tuberculous patients presenting a postoperative bronchial fistula with severe cardiopulmonary insufficiency, and in need of more surgery, we soon accepted at Hôpital Laval the theories of Laborit and Huguenard These anxıous and nervous patients, in whom the adrenergic crrculatory defences are too evident and the elevation of basal metabolısm too important, were operated under "Pharmacologic Hibernation," also called "Artificial Hibernation" We believe our experience with this neuroplegia in chest surgery to be of interest, and that our conclusions might be useful in providing some safeguards when surgery is indicated for very poor risk tuberculous patıents.

\section{General Principles and Definttions}

The basic theories essential to the understanding of this method of anaesthesia have already been described several times. They have often been confirmed experimentally and also clinically. As Huguenard said (17), "this technique is a pharmacodynamic one which, by using autonomicolytic drugs, aims at establıshing a "controlled inhibition" of the autonomic system, a neuroplegia of homeostasis and as a consequence an attentuation of the regulatory reactions, it amounts to an economical method of living with hypometabolism, muscular relaxation and a state of twlight sleep which resembles narcosis." The slight degree of hypothermia ( 4 to 5 degrees) which is present, even without cooling, is part of the general expression of the hypometabolism; the observation of the "Hôpițal Laval, Québec, P Q 
temperature is nothing more than the surest, though stil imperfect, way of checking the depth of the hibernation. In consequence, pharmacologic hibernation or attificial hibernation is the result of a pharmacodynamic process which brings about a controlled inhibition of the autonomic nervous system, a homeostatic neuroplegy. Pharmacologic hıbernation or artificial hibernation should not also be mistaken for total hibernation. In summary, pharmacologic hibernation 1s similar to artificial hibernation, but quite different from total artificial hibernaton, which necessitates generalized refrigeration of the body.

\section{Practical Application of Pharmacologic Hibernation}

\section{General Rules}

The pharmacodynamic blockade of the autonomic nervous system, essentral feature of the induction of hibernation, is accomplished by the administration of a new well-codified "Lytic Cocktall", this is a parenteral administration, progressive and sustaned, of several drugs combined in low doses.

\section{Techniques}

Preoperative preparation and sedation In order to sustain the patient in a better general conditio., and to increase his chances of recovery, Vitamin B, protem preparation and ascorbic acıd are prescribed in large doses, many days prior to surgery. Coagulants and antibiotics are also given as a routine preparation In order to faclitate pharmacologic hibernation, on the evening before the operation, and even a few days before, a preoperative sedation by the oral route is instituted with barbiturates, chlorpromazine and promethazine This ensures a calm preoperative perıod, avolding discharges of epinephrme, resulting trom fear and "stress"

Lytic cocktail On D-Day, three hours before surgery, Demerol, Largactil and Phenergan are injected intramuscularly. Two hours before, "Lytc Cocktarl," including Vitamin B (100 mgs) diluted in $250 \mathrm{cc}$ solution of 5 per cent dextrose, is administered intravenously by the continuous drip method Later on, if needed, Hydergine ( $0.9 \mathrm{mg})$ is added to the "Lytic Cocktall" for controlling the tachycardia caused by. phenothiazine derivatıves, especially Largactil. We found experimentally that with the combination Hydergine-Largactil, the cardiac output and the intracardiac pressure were less disturbed than with Largactil alone Recently, a new dibenzothiazine derivative called "Pacatal" has also been added to the "Lytic Cocktail" or given intramuscularly to provide more protection aganst cardiac reflexes. This lytic mixture is repeated as often as necessary according to the patient's needs for optmal hibernation.

Total artificial hibernation One hour before, if total artificial hibernation is wanted (for cyanotic patients, for example), ice bags are placed on various vascular areas of the patient. They are: precordial areas, Scarpa's triangle, axillae, right hypochondrium and trigeminal area. Instead of 1ce bags, cooling blankets may be used. In total artificial hibernation generalized cooling can usefully be completed by iced infusion fluids and cooled blood transfusion; Naturally, the salme used to keep the operative field moistened should be cold. The temperature of the operating room should be low: The patient should be 
naked in such a way as to mcrease the heat loss by radiation. Let us point out ummediately that this total artificial hibernation, in our opinion, must be reserved for a very few cyanotic patients.' In the vast majority of cases, pharmacologic hibernation is more adequate, and less dangerous for tuberculous patients in need of chest surgery To use total artificial hibernation without very definite indications is to expose patients to the hazards of hypothermı, which, as we demonstrate by this paper, can be avoided, with the use of the safer pharmacologic hibernation.

Duration of hibernation and supplementary measures during hibernation The duration of the administration of the "Lytic Cocktall" is proportional to the duration of the operation itself and even postoperatively to the reaction of the patient. He must remain quiet, relaxed, completely indufferent to the outside world, with complete absence of sensation, and in hypnosis deep enough to undergo surgery. With this "Lytic Cocktail," 100 per cent oxygen is admmistered during the whole procedure and on a very few cccasions a weak anaesthetic, 50 per cent nitrous oxide, is added to complete pharmacologic hibernation Rarely, thiopentone is used If it is used, less than $250 \mathrm{mgs}$. are administered by a different blood vessel than the one used for the infusion of the "Cocktall," to avold precipitation.

The pachycurare and the leptocurares are used in the same way as in clinical anaesthesia but in minimal doses.

Finally, pharmacologic hibernation in chest surgery is always completed by tracheal or endobronchial intubation, which is more easily accomplished in the hibernation subject, owing to relaxation, dry mucosae and absence of reflexes. In our cases, intubation was usually done under local anaesthesia with 5 per cent Cyclaine. Controlled or assisted respiration was used to ventilate the patient.

Supervision during "pharmacologic hibernation" More than in any other tyze of anaesthesia, the anaesthetist must check very carefully the breathing, tre pulse, the E.K G. and the blood pressure, and in addition, the rectal temperature of the hibernated patient. Strictly, the three curves-pulse, temperature and blood pressure-should be parallel In emergencies, administration of "Lytıc Cocktall" is stopped and oxygen alone is given associated with re-warming drugs if necessary.

Re-warming after hibernation. At the end of hibernation, rapid re-warming is not dangerous when it occurs in a subject capable of standing up to an abrupt resumption of tissue metabolism, that is, when the pulse and pressure curves follow the rising temperature curve In all cases, however, it is useful to slow down the return to normal conditions Thyroxine given early (because of its latent period) and intramuscularly ( 2 to 4 mgs.) seems to slow down the excessive "swings" which Laborit attributes to resumplion of pituitary function preceding the resumption of thyroid function which is less rapidly apparent. Excessive re-warming is dangerous when the subject is unable to stand up to it (disagreement between the temperature curve and those of pulse and blood pressure, which remain low, will serve as guide). If re-warming is excessive, it is necessary to reinstitute the pharmacologic neuroplegia. We now have at our disposal the following therapeutic measures when failure to re-warm is en- 
countered. (1) Discontinuation of the pharmacodynamic blockade, precordial heat, transfusions of whole blood needed, (2) addition of atropine (1/2 to $1 \mathrm{mg}$.) to the mfusion; (3) addition of "Cioramine" or "Lobeline" to the infusion; (4) intramuscular injection of acetylcholine, histamine and epinephrine.

Death during hibernation. A few technical errors, easily avoidable, could be responsible for death during hibernation.

1. Abrupt changes in position of patient during hibernation at the moment of transport to the operating room. The vasoplegia, always fairly marked, may cause cardiac insufficiency Treatment. Raising of lower extremities above head level, rapid transfusion.

2. Overdosage and accumulatıon of quinidne-lıke effects going on to complete alveolar block. Treatment: Minimal doses of ephedrine.

3. Inadequate ventulation and circulation. Treatment. Respirator with alternate positive and negative pressures, transfusions, vaso-pressor drugs.

Supplementary measures at the end of hibernation. Postoperatively, the hydratation of the hibernated patient should be carefully supervised because the needs of the subject are reduced and the urme output is also reduced. Moreover, in chest surgery, the venous system and the right heart are easily overloaded. Our routne is established as follows. (1) replacing the blood lost as evaluated in the drainage bottle, and (2) for metabolic purposes, admmistration of some fructose with vitamins. Fluid balance is maintaned routnely and antibiotics are given.

\section{Resulting Advantages for Tuberculous Patient}

With "pharmacologic hibernation" the patient benefits from suspension of the adrenergic crrculatory defences, and the metabolic increase produced by released epinephrme under "stress" is inhibited. The stabilization of the crrculation, the reduction of oxygen consumption, the decrease in metabolic reactions and the lowering of body temperature, causing passive metabolic reduction, result in greater safety against respiratory and circulatory hy joxıa, as well as against shock. These additional enhancing effects on anaestietics reduce greatly the amount of drug needed. An optimal oxygenation, a good respiratory activity without central paralysis due to anaesthetıcs, prolonged postoperative analgesia, dryness of the bronchial tract, and the practical absence of postoperative complications caused by obstructing atelectasis, laryngo-spastic or bronchospastic complications are undeniable advantages of the method. Haemorrhages, pulmonary oedema, and glottıc oedema are also favourably dımınıshed or absent.

\section{Personal Experience}

Here, a short series of thirty tuberculous patients with whorn pharmacologic hibernation was used for chest surgery is presented. These patients were from seventeen up to sixty-five years of age, male and female, thew weight varying between seventy and one hundred and forty pounds, with an average of one hundred pounds. All these patients were poor surgical risks with poor general condition, most were nervous and anxious, some presented a very severe cardiac- 
pulmonary insufficiency, a tew in the group were cases of postoperative bronchial fistulae Many of the operations were extensive with an operating time of three to four hours. To be noted the average blood loss was only $600 \mathrm{cc}$

With pharmacologic hibernation, we had a body temperature drop of four to five degrees centigrade (down to 34 degrees) with a reduced metabolısm drop of 5 per cent for each degree of temperature drop The basal metabolism was reduced from 20 to 25 per cent of the normal Obviously with total artificial hibernation, which assumes a generalized refrigeration, the degree of hypothermia is much more important (down to 30 degrees). The majority of our patients received only Lytic Cocktall and oxygen during the surgery; however, in four cases we added some pentothal to make the hypnosis deeper. The majority of our hibernated patients were fully conscious four to five hours after their surgery, and at that time the body temperature was back to normal In only a few cases, the "pharmacologic hibeination" was prolonged durıng the first twenty-four hours.

In the postoperative perıod with pharmacologic hibernation, we had less vomiting or nausea, less atelectasis, less retention of secretions and less pulmonary oedema No postoperative deaths occurred in the series as a result of the hibernation technique of these patients, two died a year after their surgery and one died two months after, from cardiac-pulmonary insufficiency.

In conclusion, with pharmacologic hibernation, we believe we have found a new weapon for salvage operations, for patients who would have been considered moperable if routme anaesthetıc procedures only had been considered. With this technique, more patients became accessible to the thoracic surgeon However, it is a complicated method of anaesthesı requiring a great deal of time and work from the anaesthetist and the nursing staff, and representing more danger for the ordinary patient than the commonly accepted technique, for this reason it should be used only by well-trained personnel and, following the indications we outlined, on the "very poor risk patients"

\section{RÉSUMÉ}

$\mathrm{Au}$ cours de ce travall, les avantages de l'hıbernation pharmacologique en chururgie pulmonaire chez le tuberculeux sont présentés.

En effet, avec l'hibernation pharmacologique, en présence d'agression (stress), les réactions crrculatorres adrénergiques de l'organısme humain sont supprimées, Il en est de même pour l'élévation du métabolisme. Tel n'est pas le cas, même en présence d'anesthésie générale profonde La stabilısation de la curculation, la dımınution de la consommatıon d'oxygène avec légère hypothermie passıve et la réduction des réactıons adrénergıques protègent d'avantage l'hıberné contre l'hypoxie circulatoire et respiratorre, en un mot contre le choc. L'analgésie et l'hypnose de l'hibernation pharmacologique permettent aussı une oxygènation optimale anns qu'une bonne ventilation et il n'y a pas de paralysie centrale anesthésıque. Les spasmes laryngés et bronchiques sont disparus et l'hémorragıe, per- et post-opératoire, dimmuée. L’analgésıe immédiate post-opératorre est faclitée et l'incidence de rétentions de sécrétıons, rédu ite au minimum. L'atélectasie massive ne se voıt presque plus et il en est ansı de l'œdème pulmonarre post-opératoire. 
-c1, une trentaine de cas sont exposés, chez qui l'hıbernation pharmacologique a été employée au cours de chirurgie pulmonarre. Tous c̊es patıents tuberculeux pulmonaures présentarent de grands risques anesthésiques: les uns étaient des anxieux avec nervosité marquée à l'égard de leur opératıon, leś autres, des insuffisants cardio-respiratorres à la limıte de l'opérabilité, enfin quelques-uns parmi ceux-là étaient porteurs d'une fistule bronchıque. Cependant, bien que la plupart d'entre eux aient subı une chırırgıe extensıve, aucun décès attribuable à l'hibernation pharmacologique fut rapporté chez ces patients.

En conclusıon, grâce à l'hỉbernation pharmacologique, quelques patıents de plus ont put bénéficier de la chirurgie taoracique pour obtenir la guérison de leur tuberculose pulmonaire. Cependant, a notre avis, la technique de l'hibernation pharmacologique doit être réservée pour les très grands risques anesthésiqueses.

\section{REFERENCES}

1 Barclay, R S, Grigor, K C, Stevenson, J G \& Welsh, T M Hypothermia with Autonomic Block for the Poor Risk Patient in Thoracic Surgery Glasgow M J, 35253 (1954)

2 BEARD, A J W Antıhistamines in Anesthesia Lancet, 2651294 (1953)

3 -... Antihistamines in Anesthesia Proc Roy Soc Med, 47407 (1954).

4 Dechêne, J P Largactl en chururgie pulmonaure Laval méd, 19214 (1954)

5 Dechêne, I P \& Hudon, F Contribution of Anaesthesia in Thoracic Surgery for Tuberculosis Proc Canad Anaesth Soc, p 72 (1953)

6 Foster, E, Foster, $\mathrm{S}$ \& MAIER, A Potentialisation anesthésique et hibernation en chirurgie thoracique Strasbourg Med p 294, no. 5 (1952)

7 - L'anesthésıe potentialısée en chırurgıe thoracıquẻ Presse méd, 60988 (1955)

8 -_- Anesthésie potentialısée en chirurgie thoracique A propos de 250 cas Bull Svndicat Natıonal des Médecins, Chıurgıens et Spécialıstes des Hôpitaux Publıcs, No 15.12 (1952)

9 Foster, E, Fosten, S, Matef, A \& Blume, H Anesthésie potentialisée en chirurgie thoracique Anes \& analg, 9250 (1952)

10 L'hibernation en chiruigie thoracique En pratique de l'hibernothérapie, p 78 Paris Masson (1954)

11. Foster, E, Foster, S, Roegel, E \& Assouad, M Hibernation, potentialisation et chirurgie thoracique Soc chir thorac franç, séance de 11 décembre 1954

12 Irmer, W \& Koss, F H Pharmacologic Hibernation in Lung Surgery. Internat. Rec Med \& Gen Prac Clin, 167337 (1954)

13 LANiEz, $C_{L}$ Potentialisation anesthésıque en chırurgıe thoracique Thèse, Lille (1954)

14 Smith, Angus. "Hubernation" Anesthesia for Major Surgery The Use of Phenothiaxine Drugs Current Researches in Anesth \& Analg, 34241 (1955)

15 Fairer, J G The Role of "IHibernation" in the Prevention and Treatment of Surgical Shock Current Researches in Anesth \& Analg., 34. 250 (1355)

16 Walsh, R D Artificial Hibernation for Poor Risk Case J rish Med Assoc, $36 \quad 155$ (1955)

17 Huguenard, P "Technique and Results of Artificial Hibernation" Its Place in Present Day Practice Poulenc Limited Scientific Department, no 78 (1953). 